\title{
Investigation of Change in Tumor Volume in Head and Neck Cancers
}

\author{
Yonca Yahsi Celen ${ }^{*}$, Orhan Zeybek ${ }^{2}$, Ayse Okumus ${ }^{3}$, Hazım Orhan Kızılkaya ${ }^{4}$, Tamer Oguz Gursoy ${ }^{5}$ \\ 1* Balikesir University, Medical Faculty, Balikesir/Turkey, (ORCID: 000000022869 664X), yoncayahsi@gmail.com \\ ${ }^{2}$ Balikesir University, Department of Physics, Balikesir/Turkey, (ORCID: 0000-0002-8379-3186), orhanzeybek@gmail.com \\ ${ }^{3}$ Yeniyuzyil University, Department of Radiation Oncology, Istanbul/Turkey, (ORCID: 0000-0003-4721-0534), ayseokm@gmail.com \\ ${ }^{4}$ Sisli Hamidiye Etfal Training and Research Hospital, Department of Radiation Oncology, Istanbul/Turkey, (ORCID: 0000-0001-6946-7539), \\ orhankizilkaya959@yahoo.com \\ ${ }^{5}$ President of Turkey Health Institutes, Istanbul/Turkey, (ORCID: 0000-0002-2568-2955), tamgursoy@yahoo.com
}

(First received 10 June 2021 and in final form 31 August 2021)

(DOI: 10.31590/ejosat.980923)

ATIF/REFERENCE: Celen, Y. Y., Zeybek, O., Okumus, A., Kızılkaya, H. O. \& Gursoy, T. O. (2021). Investigation of Change in Tumor Volume in Head and Neck Cancers. European Journal of Science and Technology, (25), 822-828.

\begin{abstract}
Twenty five patients diagnosed with head and neck cancer in the Radiation Oncology Clinic of Sisli Etfal Training and Research Hospital were included in the study. Major anatomic changes due to weight loss and tumor shrinkage are observed during radiotherapy treatment in most of the patients diagnosed with head and neck cancer. The aim of the study is to examine the changes in the dose distribution of the changes in the patient anatomy due to the weight loss observed during the treatment process and to compare the adaptive radiotherapy technique with the non-adaptive radiotherapy technique. When the treatment plans of the patients were made using the adaptive plan technique, the ipsilateral parotid volume ranged from $15.00 \pm 8.57 \mathrm{cc}$ to $10.10 \pm 5.85 \mathrm{cc}$ ( $\mathrm{p}=0.046$ ), and the contralateral parotid volume ranged from $12.21 \pm 7.34 \mathrm{cc}$ to $7.50 \pm 3.55 \mathrm{cc}$ ( $\mathrm{p}=0.002)$, Ptv 54 volume from $759.8 \pm 285.9 \mathrm{cc}$ to $432.4 \pm 126$ cc ( $\mathrm{p}=0.035)$, Ptv 60 volume from $338.7 \pm 18.9 \mathrm{cc}$ to $185.5 \pm 58.5 \mathrm{cc}(\mathrm{p}=0.003)$ and total body volume also decreased from $6380 \pm 1600 \mathrm{cc}$ to $5230 \pm 1570 \mathrm{cc}(\mathrm{p}=0.001)$, and a statistically significant decrease was observed using the T-test and Wilcoxan test. While ipsilateral parotid volume decreased at least $15 \%$ and maximum $46.3 \%$, contralateral parotid volume decreased at least $16.6 \%$ and maximum $46.9 \%$. The dose distribution results obtained from the dose volume histogram (DVH) using the adaptive radiotherapy technique are superior to the dose distribution results obtained without using the adaptive radiotherapy technique. Adaptive radiotherapy technique gives a more effective dose to the target volume and is more effective in protecting healthy tissues at the maximum rate.
\end{abstract}

Keywords: Head and Neck Cancer, Adaptive Radiotherapy, Computer Tomography (CT) Intensity Modulated Radiation Therapy (IMRT), Cone Beam Computer Tomography (CBCT), Volumetric Modulated Arc Therapy (VMAT).

\section{Tümör Hacminde Meydana Gelen Değişikliğin Baş Boyun Kanselerinde İncelenmesi}

$\ddot{\text { Öz }}$

Çalışmaya Şişli Etfal Eğitim ve Araştırma Hastanesi Radyasyon Onkolojisi Kliniğinde baş boyun kanseri tanısı konan yirmi beş hasta dahil edilmiştir. Baş boyun kanseri tanısı alan hastaların büyük bir kısmında radyoterapi tedavisi sürecinde kilo kaybı ve tümör küçülmesine bağlı ciddi anatomik değişiklikler gözlenmektedir. Çalışmanın amacı tedavi sürecinde izlenen kilo kaybına bağlı olarak meydana gelen hasta anatomisindeki değişikliklerin doz dağılımlarında oluşturdukları değişiklikleri incelemek ve adaptif radyoterapi tekniği ile adaptif olmayan radyoterapi tekniğini karşılaş̧ırmaktır.

Hastaların tedavi planları adaptif plan tekniğ kullanılarak yapıldığında aynı taraf parotis hacmi $15.00 \pm 8.57 \mathrm{cc}$ 'den $10.10 \pm 5.85 \mathrm{cc}$ 'ye $(\mathrm{p}=0.046)$, karş1 taraf parotis hacmi $12.21 \pm 7.34 \mathrm{cc}$ 'den $7.50 \pm 3.55 \mathrm{cc}$ 'ye ( $\mathrm{p}=0.002)$, Ptv 54 hacmi $759.8 \pm 285.9 \mathrm{cc}$ 'den $432.4 \pm 126 \mathrm{cc}$ ye ( $\mathrm{p}=0.035)$, Ptv 60 hacmi $338.7 \pm 18.9 \mathrm{cc}$ 'den $185.5 \pm 58.5$ cc'ye ( $\mathrm{p}=0.003)$ ve toplam vücut hacmi de $6380 \pm 1600 \mathrm{cc}$ 'den $5230 \pm 1570 \mathrm{cc}$ 'ye $(\mathrm{p}=0.001)$ küçülerek istatistiksel olarak T-testi ve Wilcoxan testi kullanılarak anlamlılık düzeyinde değerlendirebileceğimiz azalma görülmüştür. Aynı taraf parotis hacminde en az \% 15 , en fazla $\% 46.3$ hacim azalması görülürken, karşı taraf parotis hacminde en az \% 16.6, en fazla \% 46.9 volüm azalması görüldü. Adaptif radyoterapi tekniği kullanılarak doz volüm histogramından (DVH) elde etmiş olduğumuz doz dağılım sonuçları adaptif radyoterapi tekniği kullanılmadan elde edilen doz dağılım sonuçlarına göre daha üstündür. Adaptif radyoterapi tekniği hedef hacime daha etkin doz vermekte ve sağlıklı dokuları maksimum oranda korumada daha etkin bulunmaktadır.

Anahtar Kelimeler: Baş Boyun Kanserleri, Adaptif Radyoterapi, Bilgisayarlı Tomografi (BT), Yoğunluk Ayarlı Radyoterapi (YART), Volümetrik Ark Tedavisi (VMAT).

*Corresponding Author: yoncayahsi@gmail.com 


\section{Introduction}

Head and neck cancer are often benign tumors; however, they might be fatal and cause death, as well. The indications of the disease and physical examination lead to diagnose the disease, and the final diagnosis is made by biopsy. According to study findings, approximately 45,000 patients have been diagnosed annually, and the mortality rate was detected in approximately 12,000 patients due to neck cancer (Engin \& Erişen, 2003; Beyzadeoğlu et al. 2010). Recent studies showed that $6.6 \%$ of the cancers arise from head and neck regions (Jiade et al. 2010; James and Kian 2010). According to the recoveries in diagnosis and treatment, survival rates are increased. Male gender, advance age, low income level and advance cancer stage negatively affects the survival rate. As in all cancer types, early diagnosis is of vital importance.

The factors causing head and neck cancers include tobacco usage, alcohol consumption and previous exposure of the headneck region to the radiation. Ethnic liability is discussed in the generation of nasopharyngeal cancers. Exposure to sunlight for a long time increases the risk of cancer development in forehead, face and lips. Human papilloma virus (HPV) is among the reasons of head and neck cancer development. A patient having the symptoms of primary head and neck cancer has a risk of second primary head and neck cancer within the first 5 years. Malnutrition and suppression of the immune system by any reason might be effective in the development of head and neck cancer Topuz et al. 2006; Maccomb \& Fletcher 1967).

Head and neck cancers come through with local or longdistance complaints. Cancers of the nasopharynx (nasal cavity), tongue and hypopharynx (lower lip) remain latent and might appear as swelling. Therefore, a more detailed examination is required in patients having the complaints of swelling in the neck region. In general, the most common symptoms of head and neck cancers include long-lasting mouth sore, aphonia, swelling without pain in neck region (mass), difficulty in swallowing, pain affecting ears, difficulty in breathing, nasal obstruction, nasal flow and weight loss (Sangineti et al. 1997; Gemici et al. 2004).

\section{Material and Method}

Twenty-five head and neck cancer patients, aged between 1865 years, diagnosed with nasopharynx, oropharynx, larynx, tongue root and hypopharynx, who were treated at the Radiation Oncology Clinic of Sisli Hamidiye Etfal Training and Research Hospital, were included in the study. Contrast-enhanced magnetic resonance imaging (MRI) and positron emission tomography computed image (PET-CT) were requested under the same conditions as the treatment, after informing and consenting all patients. In addition, standard blood tests were performed before treatment.

The patients were informed about the treatment process and the computed tomography (CT) images of the patients were immobilized by positioning the shoulders downwards by using a thermoplastic head-neck mask and arm puller to provide the patient with the most appropriate comfort. A tongue depressor was also used in patients diagnosed with tongue root cancer.

Planning tomography of the patients was taken in the supine position for planning purposes. It is aimed that the positions of the patients during the CT image acquisition and during the radiotherapy treatment are the same.

Planning CT's and MRI images of the patients, which were taken at $3 \mathrm{~mm}$ intervals, were taken in the same positions where the patients would receive the radiotherapy treatment. Critical organs and tumor volume were drawn by a single physician using the RTOG atlas on planning CT sections to avoid differences in patient contours. Tumor volume and risk of eye, lens, optic nerve, chiasma, pituitary, mandible, temporal lobe, brain stem, medulla spinalis, parotid glands, submandibular gland, oral cavity, temporomandibular joint, larynx, thyroid gland, cochlea, pharynx muscles, and brachial plexus In order to better visualize and contour the organs under it, MRI and PET-CT planning were combined with $\mathrm{CT}$ and fusion was performed. The plans of the patients were planned using IMRT and VMAT techniques at 6MV photon energy. Simultaneous integrated boost (SIB) technique was preferred in 13 of the patients with 70 Gy for the tumor and involved lymph nodes, 60 Gy for the medium-risk region, 54 Gy for the low-risk region, in a total of 33 fractions, in 7 patients, only PTV 70 and PTV 54 volume was defined and a total of 20 patients. With the sequential boost technique, it was planned to receive 50 Gy to the elective irradiated area and 70 Gy to the tumor area and involved lymph nodes in 5 patients. The Eclipse (V.10.0) treatment planning system was used. In the dose volume histogram (DVH), treatment plans were evaluated using the dose limitations routinely applied by our clinic. Brain stem Dmax $<54$ Gy, M. Spinalis Dmax $<45$ Gy, Brachial Plexus Dmax $<66$ Gy, Parotid Mean $<26$ Gy, Submandibular Mean $<35$ Gy, Thyroid Mean $<45$ Gy, Larynx Mean $<50$ Gy, Dmax $<66$ Gy, Pharyngeal muscles Mean $<50$ Gy, Optic nerve Dmax $\leq 54$ Gy, Kiazma Dmax $\leq 54$ Gy, Mandible Dmax $\leq 70$ Gy, Mean $\leq 35-45$ Gy, CochleaDmax $\leq 60$ Gy, Mean $\leq 50$ Gy, Oral cavity Dmax $\leq 45$ Gy , Mean $\leq 35-40$ Gy, Temporal lobe Dmax $\leq 60$ Gy, Lens Dmax $\leq$ 5 Gy, Temporomandibular joint Dmax $<70$ Gy.

The patients were treated with the Varian brand Trilogy model linear accelerator device. $\mathrm{kV}$ images were taken from the patients every day. Corrections were made by taking and matching the CBCT image every other day. By matching the planning CT and CBCT image of the patients, especially the cervical vertebrae and skull base were seated in the $\mathrm{x}, \mathrm{y}, \mathrm{z}$ coordinate plane.

The weight of all patients was measured before radiotherapy and every week during the treatment period. CBCT images were taken from the patients on the 21-25 days of the radiotherapy treatment. The fusion was performed by matching the patients' CT images in the Eclipse (V.10.0) treatment planning system. A decrease in the GTV tumor volume due to the patient's weight loss and radiotherapy, and accordingly, a loosening of the patient's thermoplastic head-neck mask was observed. The patient's headneck mask was re-made. As a result, a new CT and MRI were requested from the patient and image matching was performed with fusion. The critical organs and GTV volume were reconstructed by the doctor on the new CT image, and the patient's treatment plan was reconstructed, and a three-day period was allocated for this, during which the patient entered the treatment from the old plan and when the new treatment plan was approved, the patient continued the treatment with the new plan and the new head-neck mask.

The treatment plans of the patients with and without adaptive radiotherapy were compared in terms of target volume and doses. of critical organs over DVH, and treatment gain was evaluated. Chemotherapy was administered to 22 patients simultaneously 
with radiotherapy. Statistical evaluation was made with $\mathrm{T}$ test and Wilcoxon test. (p:0.05).

\section{Results and Discussion}

A total of 25 patients participated in the study. Chemotherapy was administered to 22 patients simultaneously with radiotherapy. The number of patients who received only radiotherapy is 3 . Critical organ and target volume doses were evaluated over DVH when adaptive radiotherapy technique was applied and when it was not applied.

When the volume variations in target volume, ipsilateral and contralateral parotid parameters of medulla spinalis are examined.

\section{Statistical Analysis Results of PTV 54 Volume:}

Anderson-Darling test was performed in order to test whether the data were normally distributed or not (Figure 1, Table 1).

\section{Hypothesis:}

$\mathbf{H}_{\mathbf{0}}$ : Data are normally distributed.

$\mathbf{H}_{1}$ : Data are not normally distributed.

\section{Comment:}

As Ho is accepted, $\mathrm{H} 1$ is rejected and $\mathrm{P}>\alpha$, data are normally distributed at the significance level of $\alpha=0.05$. T-test is performed for statistically matched data as data are normally distributed and $\mathrm{n}<30$.

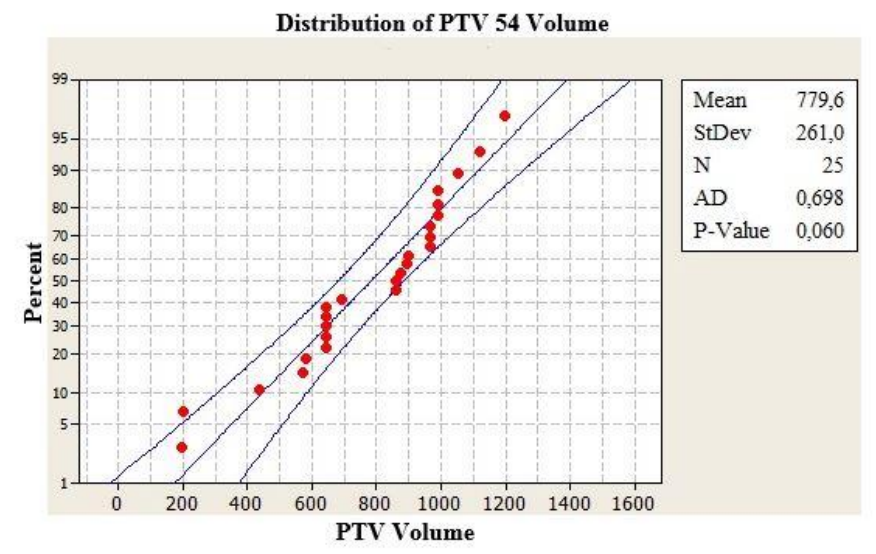

Figure 1: Distribution and analysis results of PTV 54 volume.

\section{Hypothesis:}

$\mathbf{H}_{\mathbf{0}}$ : There is no significant dose-dependent difference in volume at the PTV 54 region.

$\mathbf{H}_{1}$ : A significant dose-dependent decrease was determined in volume at the PTV 54 region.

Table 1: Analysis results of PTV 54 volume.

\begin{tabular}{lccl}
\hline \multicolumn{3}{c}{ Volume Decrease (cc) } & \\
\hline $\mathrm{N}$ & $\begin{array}{c}\text { When Adaptive Plan is } \\
\text { not performed (cc) }\end{array}$ & $\begin{array}{c}\text { After performing } \\
\text { Adaptive Plan (cc) }\end{array}$ & $\mathrm{P}$
\end{tabular}

\section{Comment:}

As $\mathrm{H}_{0}$ is rejected, $\mathrm{H}_{1}$ is accepted and $\mathrm{P}<\alpha$, a significant decrease was determined at the subjected doses at the significance level of $\alpha=0.05$.

\section{Statistical Analysis Results of PTV 60 Volume:}

Anderson-Darling test was performed (Figure 2, Table 2).

\section{Hypothesis:}

$\mathbf{H}_{0}$ : Data are normally distributed.

$\mathbf{H}_{1}$ : Data are not normally distributed.

\section{Comment:}

As Ho is accepted, $\mathrm{H} 1$ is rejected and $\mathrm{P}>\alpha$, data are normally distributed at the significance level of $\alpha=0.05$. T-test is performed for statistically matched data as data are normally distributed and $\mathrm{n}<30$.

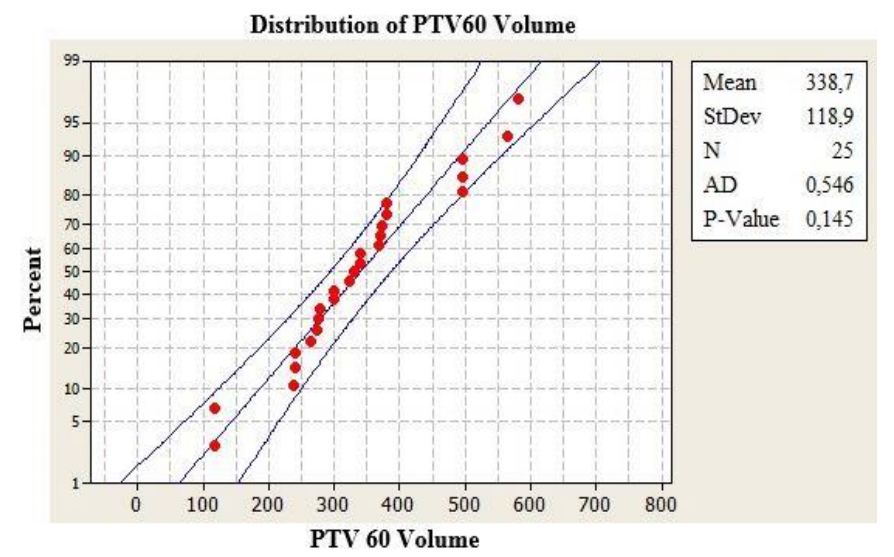

Figure 2: Distribution and analysis results of PTV 60 volume.

\section{Hypothesis:}

Ho: There is no significant dose-dependent difference in volume at the PTV 60 region.

$\mathbf{H}_{1}$ : A significant dose-dependent decrease was determined in volume at the PTV 60 region.

Table 2: Analysis Results of PTV 60 Volume.

\begin{tabular}{lcccc}
\hline & \multicolumn{3}{c}{ Volume (cc) } \\
\hline & $\mathrm{N}$ & Dose received (cc) & Adaptive CT (cc) & P \\
PTV 60 Volume & 25 & $338,7 \pm 118,9$ & $185,5 \pm 58,5$ & 0,003 \\
& & & & \\
\hline
\end{tabular}

\section{Comment:}

As $\mathrm{H}_{0}$ is rejected, $\mathrm{H}_{1}$ is accepted and $\mathrm{P}<\alpha$, a significant decrease was determined at the subjected doses at the significance level of $\alpha=0.05$ (Figure 3, Table 3).

\section{Statistical Analysis Results of Ipsilateral Parotid Volume:}

Anderson-Darling test was performed in order to test whether the data were normally distributed or not.

\section{Hypothesis:}

$\mathbf{H}_{0}$ : Data are normally distributed.

$\mathbf{H}_{1}$ : Data are not normally distributed. 


\section{Comment:}

As Ho is rejected, $\mathrm{H} 1$ is accepted and $\mathrm{P}<\alpha$, data are not normally distributed at the significance level of $\alpha=0.05$. Wilcoxon signed rank test is performed as data are not normally distributed.

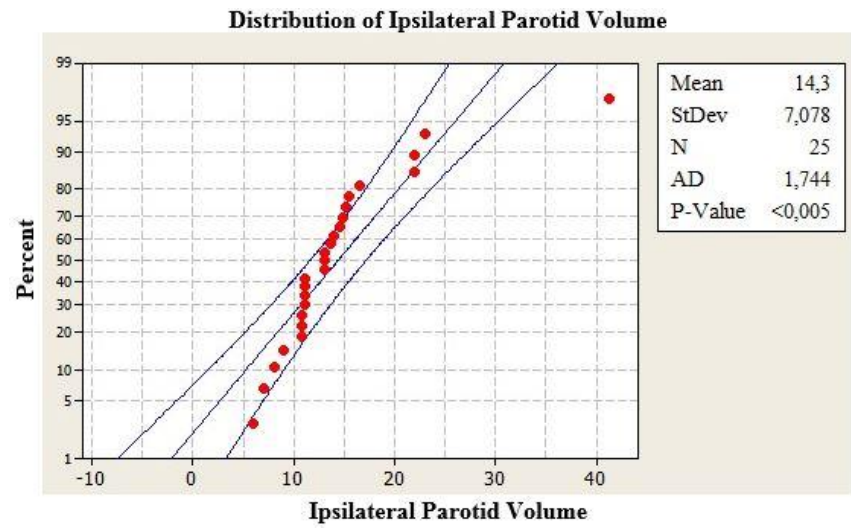

Figure 3: Distribution and analysis results of ipsilateral parotid volume.

\section{Hypothesis:}

$\mathbf{H}_{0}$ : There is no significant dose-dependent difference in volume at the ipsilateral parotid volume region.

$\mathbf{H}_{1}$ : A significant dose-dependent decrease was determined in volume at the ipsilateral parotid volume region.

Table 3: Analysis Results of Ipsilateral Parotid Volume.

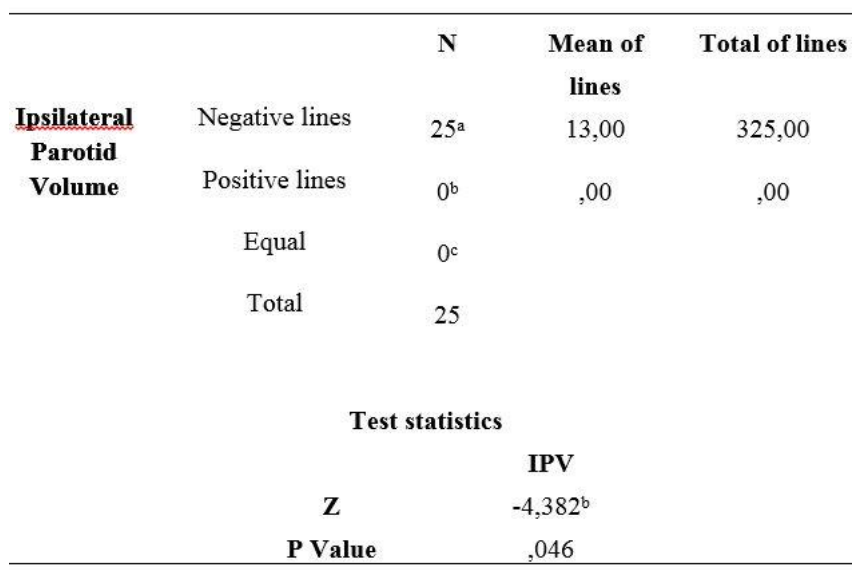

\section{Comment:}

As $\mathrm{H}_{0}$ is rejected, $\mathrm{H}_{1}$ is accepted and $\mathrm{P}<\alpha$, a significant decrease was determined at the subjected doses at the significance level of $\alpha=0.05$.

\section{Statistical Analysis Results of Contralateral Parotid Volume:}

Anderson-Darling test was performed in order to test whether the data presented in Figure 4 and Table 4 were normally distributed or not.

\section{Hypothesis:}

Ho: Data are normally distributed.

$\mathbf{H}_{1}$ : Data are not normally distributed.

\section{Comment:}

As Ho is rejected, $\mathrm{H} 1$ is accepted and $\mathrm{P}<\alpha$, data are not normally distributed at the significance level of $\alpha=0.05$. Wilcoxon signed rank test is performed as data are not normally distributed.

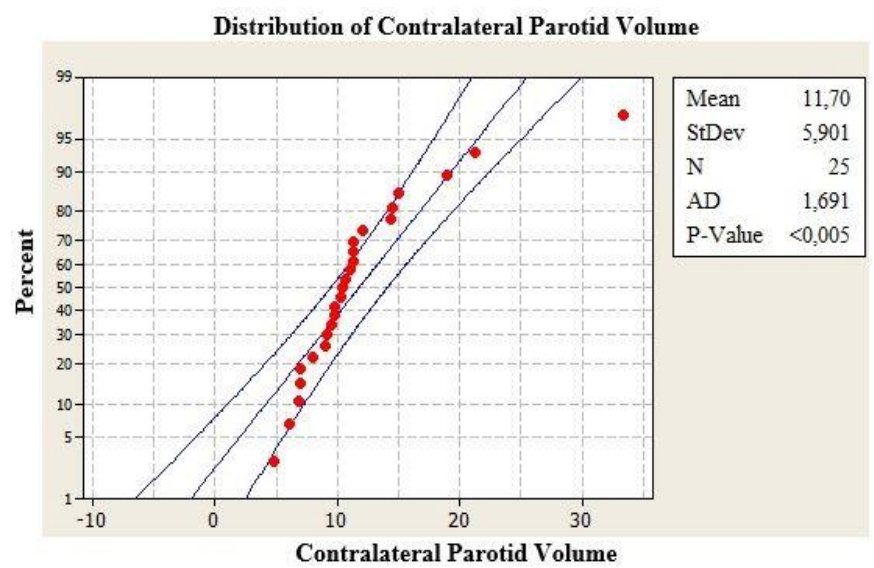

Figure 4: Distribution and analysis results of Contralateral Parotid Volume.

\section{Hypothesis:}

$\mathbf{H}_{0}$ : There is no significant dose-dependent difference in volume at the contralateral parotid volume region.

$\mathbf{H}_{1}$ : A significant dose-dependent decrease was determined in volume at the contralateral parotid volume region.

Table 4: Analysis Results of Contralateral Parotid Volume.

\begin{tabular}{clccc}
\hline & & N & Mean of lines & Total of lines \\
Contralateral Parotid Volume & Negative lines & $24^{\mathrm{a}}$ & 13,48 & 323,50 \\
& Positive lines & $1^{\mathrm{b}}$ & 1,50 & 1,50 \\
& Equal & $0^{\mathrm{c}}$ & & \\
& Total & 25 & & \\
& Test Statistics & & \\
& & $\mathbf{C P V}$ & \\
$\mathbf{Z}$ & & $-4,334^{\mathrm{b}}$ & \\
$\mathbf{Z}$ & & 022 & \\
P Value & & &
\end{tabular}

\section{Comment:}

As $\mathrm{H}_{0}$ is rejected, $\mathrm{H}_{1}$ is accepted and $\mathrm{P}<\alpha$, a significant decrease was determined at the subjected doses at the significance level of $\alpha=0.05$.

\section{Statistical Analysis Results of Total Body Volume:}

Anderson-Darling test was performed in order to test whether the data presented in Figure 5, Table 5 and Table 6 were normally distributed or not.

\section{Hypothesis:}

$\mathbf{H}_{\mathbf{0}}$ : Data are normally distributed.

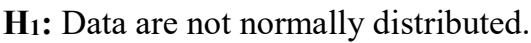




\section{Comment:}

As $\mathrm{Ho}$ is rejected, $\mathrm{H} 1$ is accepted and $\mathrm{P}<\alpha$, data are not normally distributed at the significance level of $\alpha=0.05$. As it provides the conditions of normal distribution parameters, Wilcoxon signed rank test (a non-parametric test to determine whether two related samples that are selected from the population show distribution or not is performed (Wilcoxon, 1945).

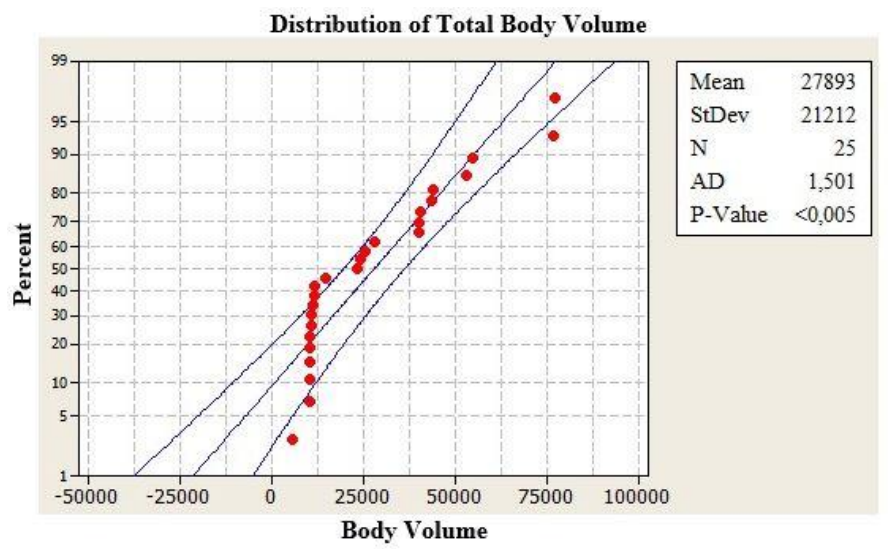

Figure 5: Distribution and analysis results of total body volume.

\section{Hypothesis:}

$\mathbf{H}_{\mathbf{0}}$ : There is no significant dose-dependent difference in volume at the total body volume region.

$\mathbf{H}_{1}$ : A significant dose-dependent decrease was determined in volume at the total body volume region.

Table 5: Analysis Results of Total Body Volume.

\begin{tabular}{|c|c|c|c|c|}
\hline \multicolumn{5}{|c|}{ Rows Total } \\
\hline Total body & \multicolumn{4}{|c|}{284,00} \\
\hline volume & \multicolumn{4}{|c|}{41,00} \\
\hline & \multicolumn{4}{|c|}{ Total body volume } \\
\hline $\mathbf{Z}$ & \multicolumn{4}{|c|}{$-3,269^{b}$} \\
\hline P Value & \multicolumn{4}{|c|}{, 001} \\
\hline & & $\mathbf{N}$ & $\begin{array}{l}\text { Mean of } \\
\text { lines }\end{array}$ & $\begin{array}{l}\text { Total } \\
\text { of } \\
\text { lines }\end{array}$ \\
\hline \multirow{5}{*}{$\begin{array}{l}\text { Total body } \\
\text { volume }\end{array}$} & Negative lines & $23^{\mathrm{a}}$ & 12,35 & 284,0 \\
\hline & & & & 0 \\
\hline & Positive lines & $2^{\mathrm{b}}$ & 20,50 & 41,00 \\
\hline & Equal & \multicolumn{3}{|l|}{$0^{c}$} \\
\hline & Total & \multicolumn{3}{|l|}{25} \\
\hline \multicolumn{5}{|l|}{ est statistics } \\
\hline & \multicolumn{4}{|c|}{ Total body volume } \\
\hline $\mathbf{Z}$ & \multicolumn{4}{|c|}{$-3,269^{b}$} \\
\hline P Value & \multicolumn{4}{|c|}{, 001} \\
\hline
\end{tabular}

\section{Comment:}

As $\mathrm{Ho}$ is rejected, $\mathrm{H} 1$ is accepted and $\mathrm{P}<\alpha$, a significant decrease was determined at the subjected doses at the significance level of $\alpha=0.05$.
Table 6: The variation between first CT plan and adaptive CT in terms of tumor, total volume and parotid volume.

\begin{tabular}{lccc}
\hline & $\mathbf{1}^{\text {st }}$ CT plan (cc) & Adaptive CT plan (cc) & P value \\
\hline PTV 54 & $759.8 \pm 285.9$ & $432.4 \pm 126.0$ & 0.035 \\
\hline PTV 60 & $338.7 \pm 118.9$ & $185.5 \pm 58.5$ & 0.003 \\
\hline Ipsilateral parotid & $15.00 \pm 8.57$ & $10.10 \pm 5.85$ & 0.046 \\
\hline Contralateral parotid & $12.21 \pm 7.34$ & $7.50 \pm 3.55$ & 0.022 \\
\hline Total body volume & $6,380 \pm 1,600$ & $5,230 \pm 1,570$ & 0.001 \\
\hline
\end{tabular}

\section{Conclusions and Recommendations}

Tumor volume of the patient has been changed due to weight loss during the treatment. This condition is unavoidable especially in head and neck tumors; thereof, normal tissues expose to more radiation owning to these variations and tumor volume receives lesser dose.

It is possible to enable more conformal therapies by imageguided radiotherapy (IGRT) and thus increase the efficacy of the treatment and reduce the possible side effects. Advanced radiotherapy techniques, such as IGRT, reduce PTV margins and target tissue, and enables to give higher tumor doses (Hansen et al. 2006). Set up errors and variations related to organ movement can be improved by IGRT.

In conditions of "advanced conformal radiotherapy" approaches, anatomical variations throughout fractional radiotherapy might have significant dosimetric effects, such as intensity modulated radiotherapy (IMRT). Therefore, a pilot study was performed to find an answer to this question by using common imaging method during RT implementation. Recently, in-room CT imaging systems and integrated CT accelerating systems are broadly reached, position and anatomical views of the patient are easily displayed while patient is at therapy position. In the present study, it was focused to detect geometrical and volumetric variations as quantity (Barker et al. 2004). In addition, the medial migration of parotid glands reveals a significant correlation with weight loss during the treatment. This statistically significant weight loss is the indicator of huge amount of medial parotid shift.

During the revision of treatment plan, CT scanning becomes a necessity to reveal the quantity of this shift. In that case, the level of radiation exposure to the medial parotid shift might be increased according to the inital treatment plan (Barker et al. 2004).

Lee et al. found the day-to-day variations in the center-ofmass distance and volume as $1.61 \mathrm{~mm}$ and $4.36 \%$ by using megavoltage CT, respectively. In the present study, the mean migration distance of both parotidis from the center was detected as $4.3 \mathrm{~mm}$ during the treatment (Lee et al. 2008). The mass reduction was approximately $1.8 \% / \mathrm{d}$ for both primary tumors and relevant nodes. This value is also close to the previously defined ratio. The ratio of parotid was reduced in the ratio of about $0.6 \% / \mathrm{d}$. These anatomical variations were resulted in significant volume and COM positional variations during the radiotherapy.

These kinds of geometrical variations in the contour and location of the tumor might be ended up with the most appropriate treatment, such as IMRT, especially when high-level conformal therapies are used (Barker et al. 2004). 
Barker et al. investigated 14 head and neck cancer patients having at least $4 \mathrm{~cm}$ primary and/or cervical nodule disease and they found that the rate of reduction of GTV was $0.2 \mathrm{~cm}^{3}$ between the treatments and $1.8 \%$ daily, and thus this reduction meant that $69.5 \%$ of the initial GTV was the medial total relative loss at the end of the treatment. This ratio is related to high rate of weight loss and medial shift in the center of parotid mass in the patient. Medial shift in the center of the tumor should also be noted. The loss of GTV is mostly asymmetric and the distance of medial shift of the mass center is $3.3 \mathrm{~mm}$ at the end of the treatment. Day-today reduction in the parotid volume and the loss of median volume at the end of the treatment are $0.19 \mathrm{~cm}^{3}$ and $28.1 \%$, respectively. In general, medial shift is $3.1 \mathrm{~mm}$ at the end of the treatment. Medial shift is significantly related to weight loss during the treatment. Dosimetric aspects of the anatomical deformations were also handled for the re-planning of the selected patients in the middle of the chemotherapy (Barker et al. 2004).

In previous studies, significant variations were recorded in dosimetric parameters including GTV, CTV, PTV, parotid gland and medulla spinalis. A significant relationship was detected between dosimetric variations and weight loss, number of fractions, skull and positional variations submaxilla cervical vertebra.

Therefore, it is adequate to observe anatomical variations, but also it is necessary to investigate positional variations that might arise during IMRT treatment in head and neck cancers (Hansen et al. 2006).

In the present study, a statistically significant reduction was observed in the volumes of PTV 54 and PTV 60, from $759.8 \pm$ $285.9 \mathrm{cc}$ to $432.4 \pm 126 \mathrm{cc}$ and from $338.7 \pm 118.9 \mathrm{cc}$ to $185.5 \pm$ $58.5 \mathrm{cc}$, respectively, when adaptive plan was performed. Weight loss or reduction in tumor size resulted in expansion of the mask in patients receiving IMRT treatment, and it was recommended to repeat CT scan procedure by using a new mask (Ahn et al. 2011).

In addition to the careful observation of clinical and anatomical parameters, weight loss and variations in skin contour, CT-based image-guided radiation therapy (IGRT) should be used more commonly to evaluate anatomical and positional variations of these patients (Ahn et al. 2011). The size, location and surrounding critical organs of the tumor undergo variations at the end of week-long treatment. ART is aimed to correct the morphological variations tissue in patients, such as post-treatment tumor and variations in healthy tissues. It uses CBCT system to reveal the position and size of the tumor at the time of treatment (David et al. 2011).

Adaptive radiotherapy brings a new dimension to the treatment plans of the patients, and it presents certain potential solutions against position-and anatomy related problems. This study discussed potential solutions to minimize the difference between received dose during the treatment and planned dose by the patients receiving head and neck malignity treatment.

While IMRT provides the maximum coverage of the tumor, it preserves OARs and thus causes potential increase in therapeutic index. In current IMRT implementations, treatments are planned with pre-treatment CT scan images. By means of this approach, potential variations in the anatomy and localization of the patient are not taken into consideration for a treatment period of 5 to 7 weeks. These variations might be related to the reduction of tumor and nodule size, weight loss, variations in muscle mass and fat or migration of body fluid. These kinds of modifications

e-ISSN: 2148-2683 might cause significant alterations in terms of the localization, shape and size of tumor and critical organs (David et al. 2011).

In the present study, CBCT was used in order to monitor and follow the variations in the tumor size and accuracy of the setup. It is important to note the significant variations in PTV and skin contour. When the pre-treatment images in planning CTs were compared to planning CT and CBCT images obtained in the middle of the treatment, a significant difference was detected in target tumor volume. This finding showed correlation with the findings of Barker et al. and Hansen et al. This study showed that CBCT was a highly effective tool for the identification of variation in tumor size (Barker et al. 2004).

Patients with head and neck cancer suffer from important anatomical variations according to the treatment response of the tumor or weight loss during the treatment. The findings of certain studies showed that the volume of parotid salivary gland was reduced and mean translocation was observed in its mass.

Pilot studies defining the clinical results in accordance to adaptation of applied doses and especially the dose variations delivered to target tissue and organs at risk direct to novel studies in adaptive radiation therapy (ART) during the treatment in patients treated with adaptive period. None of the previous studies tried to measure the potential effects of dosimetric variations between planned and real organ doses on the clinical findings.

Castadot et al. stated a significant reduction between mean cumulative parotid dose obtained from initial treatment plans and mean parotid volume obtained as a result of re-planning the treatment in patient with high GTV and patient who experienced significant reduction in the tumor size, and they concluded that these patients could benefit from adaptive radiotherapy. In the present study, mean parotid dose showed a significant reduction when performing adaptive plan.

Barker et al. found that neck tumor was reduced to $69.5 \%$ in patients with nodular disease over $4 \mathrm{~cm}$. This ratio is related to weight loss and medial shift at the center of parotid mass which is also noted separately. They also investigated the dosimetric aspects of the anatomical deformations in the examination of patients who were selected for re-planning in the middle of the chemotherapy (Barker et al. 2004).

In the present study, a significant reduction was detected in target and parotid volume when ART was performed, and a significant decline was observed in the mean dose of both parotidis, which enabled a significant increase in swallowing and quality of life by preserving salivary glands.

Image guided controls revealed that $80 \%$ of the patients showed complete or almost complete regression at the $3^{\text {rd }}$ and $6^{\text {th }}$ months. Re-planning was recommended as reduction was observed in the tumor volume due to weight loss between the fractions of 21 to 25 or the response of tumor to the radiotherapy.

\section{Acknowledge}

Approval for the study was obtained from the Ethics Evaluation Committee of Sisli Hamidiye Etfal Training and Research Hospital

\section{References}

Ahn, P. H., Daniel, O., Chen, C.C., Ahn, A. I., Hong, L., Scripes, P.G., Shen, J., Lee, C.C, Miller, E. Kalnicki, S. and Garg, M. 
K. (2011). Adaptive planning in intensitymodulated radiation therapy for head and neck cancers: single-institution experience and clinical implications. Int. J. Radiat. Oncol. Biol. Phys., 677-685.

Barker, J. L., Jr, Garden, A. S. and Ang, K.K. (2004). Quantification of volumetric and geometric changes occuring during fractionated radiotherapy for head-and neck cancer using an integrated CT/linear accelator system. Int. J. Radiat. Oncol. Bio. Phys., 960- 970.

Beyzadeoğlu, M., Özyiğit, G. ve Ebruli, C. (2010). Basic radiation oncology, 30, 148, 155-169, 209-222.

David, L. S., Adam, S., Garden, J. T., Yipei Chen, B. S., Yongbin Z., Jan L. and Mark, S. (2011). Adaptive radiotherapy for head-and-neck cancer: initial clinical outcomes from a prospective trial"., International Journal of Radiation Oncology Biology Physics, 83 (3), 986-993.

Engin, K. ve Erişen L. (2003) Baş-boyun kanserleri, İstanbul: Nobel Tip Kitapevi, 920-934.

Gemici, C., Mayadağlı, A. ve Parlak, C. (2004) Radyasyon onkolojisi tedavi kararları, İstanbul: Nobel Tip Kitapevi, 706803.

Hansen, E. K., Bucci, M. K., and Quivey, J. M. (2006). Repeat ct imaging and replanningduring the course of $1 \mathrm{mrt}$ for head and neck cancer", Int. J. Radiat. Oncol. Bio. Phys., 64, 355-362.

James, D. C. and Kian, A. (2010). Radiation oncology: rationale, technique, results, 161 .

Jiade, J. L., Jay, S. C. and Anne W. M. L. (2010). Nasopharyngeal cancer, multidisciplinary management, 6 .

Lee, C., Langen, K. M., Lu, W. (2008). Hainerl, J., Schnarr, E. and Ruchala, K. J.,"Evaluation of geometric changes of parotid glands during head neck cancer radiotherapy using daily MVCT and automatic deformable registration", Radiother. Oncol., 89 (1), 8-81.

Maccomb, W. S. and Fletcher, G. H. (1967). Cancer of the head and neck, Baltimore: Williamsand Wilkins, 179-212.

Sangineti, G., Geara, F. B., and Garden, A. S. (1997). Carcinoma of the nasopharynx treated by radioteherapy alone: determinants of local and regional control. Int. J. Radiat. Oncol. Biol. Phys., 37, 985-996.

Topuz, E., Aydıner, A. ve Karadeniz A. N. (2006). Baş-boyun ve tiroit kanserleri, Klinik Onkoloji, İstanbul: İstanbul Üniversitesi Onkoloji Enstitüsü Yayınları, 161-162.

Wilcoxon, F. (1945). İnvidiual comprarisons by ranking methods" Biometrics Bulletin, 1(6), 83-80. 